UDC 330.15:502.52

\title{
ECONOMIC INCENTIVES FOR ENVIRONMENTALLY HEALTHY ENTREPRENEURSHIP IN UKRAINE
}

\section{ЕКОНОМІЧНИЙ ІНСТРУМЕНТАРІЙ СТИМУЛЮВАННЯ ЕКОЛОГО-БЕЗПЕКОВОГО ПІДПРИЄМНИЦТВА В УКРАЇНІ}

\author{
Leskiv Halyna \\ Lviv State University of Internal Affairs \\ ORCID: https://orcid.org/0000-0002-4900-9466 \\ Hobela Volodymyr \\ Lviv State University of Internal Affairs \\ ORCID: https://orcid.org/0000-0001-7438-2329 \\ Lesyk Nazar \\ Lviv State University of Internal Affairs \\ ORCID: https://orcid.org/0000-0001-8116-5373 \\ Леськів Галина Зеновіївна \\ кандидат технічних наук, \\ Львівський державний університет внутрішніх справ \\ Гобела Володимир Володимирович \\ кандидат економічних наук, \\ Львівський державний університет внутрішніх справ \\ Лесик Назар Андрійович \\ аспірант, \\ Львівський державний університет внутрішніх справ
}

The study is devoted to the current problem of the formation and development of environmental entrepreneurship. The urgency of this problem is substantiated researched the unsatisfactory level of environmental safety of Ukrainian enterprises and the crisis of the environment. The study's purpose was to analyze the economic tools to stimulate environmental entrepreneurship, structural and functional characteristics and classification of tools to determine priority areas for improvement. The study forms a definition of economic tools to stimulate environmental entrepreneurship. Theoretical analysis and structural and functional characteristics of economic tools were performed. A scientific and methodological approach to the classification of economic tools was proposed, which allowed improving the system of its classification. Based on the results of the study, the main directions of development and improvement of economic tools to stimulate environmental entrepreneurship were proposed.

Keywords: economic tools, entrepreneurship, economic development, transformation, greening.

Дослідження присвячено актуальній проблемі фрормування та розвитку екологічного підприємництва як засобу забезпечення сталого розвитку суспільства та економіки. Обґрунтовано актуальність даної проблеми 3 огляду на незадовільний рівень екологічної безпеки українських підприємств, значний рівень екологічної шкоди, що завдає бізнес та кризовий стан довкілля. Важливість дослідження проблематики підкреслена недостатнім рівнем розвитку економічного інструментарію стимулювання екологічного підприємництва в Україні. Метою дослідження є теоретичний аналіз економічного інструментарію стимулювання екологічного підприємництва, його структурно-срункціональна характеристика та удосконалення системи класисрікації інструментів для визначення пріоритетних напрямів його удосконалення. У дослідженні проаналізовано підходи до визначення поняття економічного інструментарію. В результаті аналізу сорормовано авторське визначення економічного інструментарію стимулювання екологічного підприємництва, що на відміну від існуючих розкриває також його безпекову сутність, як засобу протидії екологічним загрозам для підприємства. Охарактеризовано сутність економічного інструментарію у сучасних економічних системах та наголошено на його важливості для екологічно безпечного розвитку бізнесу та держави загалом. Здійснено теоретичний аналіз економічного інструментарію, визначено його основні складові та принципи на яких його слід формувати. 
Реалізовано структурно-фрункціональну характеристику економічного інструментарію, встановлено основні цілі та завдання інструментарію щодо стимулювання екологічного підприємництва. Проведений теоретичний аналіз наявних систем класифікації економічного інструментарію дозволив виокремити його основні недоліки. Запропоновано науково-методичний підхід до класифікації економічного інструментарію, що передбачає видозмінені ознаки та групи класифікації. Ґрунтуючись на результатах дослідження запропоновано основні напрями розвитку та удосконалення економічного інструментарію стимулювання екологічного підприємництва.

Ключові слова: економічний інструментарій, підприємництво, економічний розвиток, транссормація, екологізація.

Исследование посвящено актуальной проблеме фрормирования и развития экологического предпринимательства. Обоснована актуальность данной проблемы, учитывая неудовлетворительный уровень экологической безопасности украинских предприятий и кризисное состояние окружающей среды. Целью исследования является анализ экономического инструментария для стимулирования экологического предпринимательства, структурно-фрункциональная характеристика и классификация инструментов для определения приоритетных направлений его усовершенствования. В исследовании сформировано определение экономического инструментария для стимулирования экологического предпринимательства. Проведен теоретический анализ и структурно-фуункциональная характеристика экономического инструментария. Предложен научно-методический подход к классификации экономического инструментария, что позволило улучшить систему его классификации. Основываясь на результатах исследования, предложены основные направления развития и усовершенствования экономического инструментария стимулирования экологического предпринимательства.

Ключевые слова: экономический инструментарий, предпринимательство, экономическое развитие, трансорормация, экологизация.

Problem statement. Overcoming environmental problems in the period of globalization and scientific and technological revolution necessitates the formation of a system of environmentally healthy economic development.

To form such a model of development, it is necessary to develop an economic mechanism based on ecological and economic principles of management. Therefore, there is a need to clarify the motives that motivate companies to focus on environmentally healthy production and sales. It is worth noting that in modern conditions, a key role in this process is played by economic tools, as the world is dominated by the principles of market economy and market relations. However, according to modern researchers, a market economy is unable to strike a balance between economic efficiency, rational income redistribution and environmental health. In other words, to ensure the sustainable development of society. Moreover, there is a need to form a system of measures that would encourage the development of environmental entrepreneurship. To do this, it is necessary to reallocate a significant amount of financial resources to take appropriate economic incentives.

Therefore, the system of measures of economic stimulation of ecological entrepreneurship is an important element of ensuring ecological and economic security of the state.

Theoretical framework and literature review. The studies of numerous foreign and domestic scientists are devoted to the study of the main theoretical and practical aspects of economic stimulation of ecological entrepreneurship.
Datsenko's O. works are devoted to the study of the principles of the formation of economic tools for stimulating ecological entrepreneurship in the context of Ukraine's European integration [2]. An important area that was studied was the direction of providing economic incentives and the development of tools for greening investment activities [4]. Scientists have also explored ways to stimulate environmental entrepreneurship and green production through the use of environmental taxes [9]. Prykhodko's, V. [10] researches are devoted to the study of economic tools for ensuring regional ecologically safe development. Scientists have studied greening as a means of ensuring sustainable economic development and economic measures as a tool of greening [8]. The attention of scientists, in particular Syniakevych I., was attracted by the problems of the social development greening in the framework of counteracting global environmental problems and studying the necessary economic tools [12]. A significant number of foreign researchers have studied and researched this issue. Chu J., Shao C., Emrouznejad A., Wu J., and Yuan Z. [1] are devoted to the study of the main means of economic stimulation of greening of business and formation of the system of economic emissions trading. Researchers have studied the relationship and place of economic instruments and incentives in the environmental policy of the state [7]. Scientists have not overlooked the problem of using economic incentives to regulate emissions of toxic and hazardous substances [6]. The research of Lavee D. [5] is devoted to solving the topical issue of choosing 
the most optimal tools between economic and administrative.

In general, this issue is well researched, but several issues remain open. In particular, the field of economic tools to stimulate environmental entrepreneurship and its detailed analysis needs to be studied.

Article objectives. The purposes of the article are to carry out a thorough analysis of the economic tools to stimulate environmental entrepreneurship; implementation of its structural and functional characteristics; study of the existing system of classification of economic incentives; development of ways and priority directions of improvement of economic tools of stimulation of ecological business.

Results and discussions. Various researchers believe that economic incentives are the most effective way to protect the environment. In addition, these methods not only improve the environment but also prevent environmental threats [2].

That is, ensuring environmentally healthy development involves the use of economic instruments to improve the environment, encourage businesses to green production and conduct environmentally healthy business. The importance of this is because a satisfactory state of the environment is of the paramount importance for society, provided by the right to normal living conditions of all its members.

Economic tools are a more effective and efficient means than means of administrative influence on nature users. However, scholars claim that in Ukraine the use of economic tools is in its infancy and development [3].

Under the economic instruments to stimulate environmental entrepreneurship will be understood a system of measures and techniques aimed at regulating relations in the use of natural resources, to rationalize nature, form a system of protection and restoration of the environment, stimulate greening, by attracting and redistributing funds.

That is, it is a system of measures that allows the rational distribution of funds received from environmental payments to prevent the occurrence of environmental crises, anthropogenic disasters and minimize their negative impact - that is, ensure the appropriate level of environmental safety. Including more efficient and resource-saving use of natural resources, as well as encouraging businesses to use this method of nature.

It is advisable to identify the basic principles of the formation of economic instruments. Since greening can be considered as a process of environmental policy, it is advisable to consider the basic principles of formation of tools of politics, proposed by I. Sinyakevich [12]. Based on the results of the analysis of these principles, we consider it appropriate to identify the following principles of the formation of economic instruments of greening.

Such principles include:

- the principle of transformation of external environmental effects into internal ones;

- the principle of integration of mandatory instruments with voluntary ones;

- the principle of transformation of economic instruments into instruments of environmental policy.

The main objectives of the use of economic instruments include the following components:

- limiting the use of environmental resources;

- reduction of the general level of environmental pollution;

- encouraging nature users to use environmentally healthy and acceptable methods and techniques.

The tasks performed by economic instruments include the following:

- application of economic incentives in the process of implementing environmental and economic policy;

- liberalization of actions for nature users;

- integration of state and local authorities in the process of implementing environmental and economic policy;

- purposeful improvement of the ecological state of the environment;

- greening the consciousness of the population [8].

Among a large number of greening tools scientists propose their division into three groups $[6 ; 8 ; 11]$. The first group includes tools that force nature users to act within environmental requirements and implement environmental measures. The second group includes tools that encourage entrepreneurs to protect the environment. The third group includes economic measures aimed at supporting those nature users who carry out environmental activities [9].

It is difficult to trace the difference between tools that encourage entrepreneurs to protect the environment and tools that support entrepreneurs who carry out environmental activities. Therefore, we consider that it is advisable to consider the division into only two blocks - the restriction tools and incentive tools listed in table 1.

For the common understanding of the essence of economic tools of stimulation of 
Economic incentives classification by the essence of the impact

Table 1

\begin{tabular}{|c|c|}
\hline LIMITATION & STIMULATION \\
\hline Natural resources usage fees & Preferential taxation \\
\hline Payment for environmental pollution & Preferential lending \\
\hline $\begin{array}{c}\text { Payments for the use of the environment for } \\
\text { placement of production waste }\end{array}$ & $\begin{array}{c}\text { Accelerated depreciation fixed assets, } \\
\text { resource-saving and environmental } \\
\text { appointment }\end{array}$ \\
\hline Fines and sanctions for excessive use of resources & Environmental insurance \\
\hline Payment for noise pollution & Arrangement of "ecological market" \\
\hline Payment for radiological contamination & Grants, grants, subsidies \\
\hline Customs duties and restrictions & Ecological certification and environmental audit \\
\hline
\end{tabular}

Source: adopted from [8; 9]

ecological business, we suggest carrying out its further classification. Based on the results of the analysis, we believe that the classification should be carried out according to the following features of the table 2 .

In the conditions of digitalization of society and the rapid dissemination of information in social networks, the formation of a positive ecological image through the implementation of various actions to protect and preserve the environment becomes quite relevant. Public organizations play an important role in this process, in particular, the dissemination of information through social networks on various environmental safety measures contributes to the rapid dissemination of information and the involvement of a large number of people in such activities.

It is worth considering the scope of economic tools of greening. It is manifested in the following areas: economic (lending, taxation, depreciation rates); environmental (payments for use, pollution, discharges); social.

The use of economic tools for the implementation of socio-psychological influence can be manifested through the media by supporting and stimulating the following measures:

Table 2

\section{Economic incentives classification}

\begin{tabular}{|c|c|c|}
\hline FEATURE & GROUP & INCENTIVES \\
\hline \multirow{2}{*}{$\begin{array}{l}\text { The essence } \\
\text { of the impact }\end{array}$} & Limitation & $\begin{array}{l}\text { Payments for use, pollution charges, customs duties, licensing, } \\
\text { quotas, etc. }\end{array}$ \\
\hline & Stimulation & Environmental insurance, organic production, preferential taxation \\
\hline \multirow{4}{*}{ Territorial level } & Global & $\begin{array}{l}\text { Trade-in pollution quotas under the Kyoto Protocol, eco-labeling, } \\
\text { environmental audit }\end{array}$ \\
\hline & National & $\begin{array}{l}\text { Preferential taxation, formation of the ecological market, customs } \\
\text { payments, accelerated depreciation }\end{array}$ \\
\hline & Regional & $\begin{array}{l}\text { Regional environmental programs: waste management, preservation } \\
\text { of natural landscapes, restoration of soil cover, forest cover }\end{array}$ \\
\hline & Local & $\begin{array}{l}\text { Collection and processing of certain types of waste (batteries, } \\
\text { plastic), carrying out threshing to clean reservoirs and forests }\end{array}$ \\
\hline \multirow[t]{2}{*}{ Time sign } & Permanent & $\begin{array}{l}\text { Preferential taxation, pollution charges, fines, and sanctions for } \\
\text { excessive use of resources }\end{array}$ \\
\hline & Temporary & Grants, grants, talks, public environmentally-oriented actions \\
\hline \multirow{4}{*}{$\begin{array}{l}\text { Form of } \\
\text { manifestation }\end{array}$} & Payments & Fee for resources, fee for pollutant emissions \\
\hline & Costs & Fines, sanctions for pollution and excessive use of resources \\
\hline & $\begin{array}{l}\text { Economic } \\
\text { benefits }\end{array}$ & Tax benefits, lending, eco-labeling, organic production, etc. \\
\hline & $\begin{array}{l}\text { Financial } \\
\text { payments }\end{array}$ & Grants, subsidies, grants \\
\hline \multirow{2}{*}{$\begin{array}{l}\text { Areas of } \\
\text { application }\end{array}$} & Economic & Lending, taxation, depreciation rates \\
\hline & Ecological & Payments for use, discharges of pollutants \\
\hline
\end{tabular}


- popularization of ideas of ecologically safe business and increase of the level of ecological consciousness of the population;

- formation of ecologically-oriented social advertising campaigns;

- promotion of products of manufacturers who use environmentally healthy production methods and produce environmentally healthy products;

- promotion of green tourism and ecologically safe leisure, etc.

Having performed the analysis, we summarize that the priority areas for the development of economic tools of environmental entrepreneurship are:

- improvement of the system of taxation and customs regulation to limit the production and consumption of goods that have an eco-destructive impact on the environment;
- improvement of the system of financial and credit support of greening processes;

- development of innovative market methods of regulating the demand for products, taking into account its environmental friendliness;

- the use of economic tools to ensure socio-psychological methods of influencing entrepreneurs and consumers.

Conclusions. Research has identified the need and importance of developing economic tools to stimulate environmental entrepreneurship in Ukraine to ensure sustainable development. As a result of theoretical analysis, the main purpose, goals, principles and objectives of economic tools are established. It was proposed to improve the system of classification of economic instruments, which allowed identifying the main areas of improvement of economic tools to stimulate environmental business.

\section{REFERENCES:}

1. Chu, J., Shao, C., Emrouznejad, A., Wu, J., \& Yuan, Z. (2021) Performance evaluation of organizations considering economic incentives for emission reduction: A carbon emission permit trading approach. Energy Economics, 101, 105398.

Datsenko, O. F. (2020) Ekonomichni instrumenty ekolohizatsii ekonomiky Ukrainy na shliakhu do EU [Economic instruments of greening Ukraine's economy on the way to the EU]. Eurasian Academic Research Journal, 2(34), 53-59. Retrieved from: http://elar.khnu.km.ua/jspui/handle/123456789/9212

2. Hobela, V. (2021) Economic and safety greening: theory and practice. LDUVS.

3. Klimenko, O. V. (2010) Ekonomichni instrumenty ekolohizatsii investytsiinoi diialnosti [Economic tools for greening investment activities]. Bulletin of Khmelnytsky National University, 2, 198-202.

4. Lavee, D. (2020) Are economic tools preferable to direct regulatory measures in achieving environmental goals?. Environmental Policy and Law, (Preprint), 1-11.

5. Macauley, M. K., Bowes, M. D., \& Palmer, K. L. (2017) Using economic incentives to regulate toxic substances. Routledge.

6. Ouvrard, B., \& Stenger, A. (Eds.) (2019) Incentives and Environmental Policies: From Theory to Empirical Novelties. John Wiley \& Sons.

7. Petrovska, A. S. (2019) Ekolohizatsiia ekonomiky Ukrainy v konteksti modeli staloho rozvytku [Greening of Ukraine's economy in the context of the model of sustainable development]. Problems and Prospects of Economics and Management, 4(20), 95-104.

8. Polischuk, V. (2018) Rehuliuvannia mekhanizmiv ekolohizatsii ekonomiky za dopomohoiu realizatsii ekolohichnoho opodatkuvannia [Regulation of mechanisms for greening the economy through the implementation of environmental taxation]. Economic journal of Lesya Ukrainka Volyn National University, 1(13), 111-118.

9. Prykhodko, V. P. (2012) Orhanizatsiino-ekonomichni instrumenty ekolohizatsii rehionalnoho rozvytku [Organizational and economic tools for greening regional development]. Economics of Nature Management and Environmental Protection, 170-175.

10. Rehbinder, E., \& Stewart, R. (2020) Environmental protection policy. De Gruyter.

11.Syniakevych, I. M. (2011) Ekolohizatsiia suspilnoho rozvytku yak instrument podolannia ekolohichnykh zahroz [Greening of social development as a tool for overcoming environmental threats]. Regional Economy, 4, 14-20. 